\title{
IDENTIFYING ISLAMIC VALUES ON GREEN ARCHITECTURAL CONCEPT: QUANTITATIVE APPROACHES TO CONTENT ANALYSIS
}

| Received August 23 2019 | Accepted November 15 2019 | Available online December $20^{\text {th. }} 2019$

DOI http://dx. doi.org/10.18860/jia.v5i4.7568 |

Aulia Fikriarini Muchlis

Institut Teknologi Bandung

Jalan Ganesha 10 Bandung, 40132

Indonesia

fikriarini@gmail.com

\section{Dewi Larasati}

Institut Teknologi Bandung

Jalan Ganesha 10 Bandung, 40132

Indonesia

\section{Sugeng Triyadi}

Institut Teknologi Bandung

Jalan Ganesha 10 Bandung, 40132

Indonesia

\begin{abstract}
The paper investigates to explore Islamic religious values which related to environment Maintaining environmental balance is the primary human task. Besides, religious belief is a source of ethics and morality. It is a guidance of truth for making decisions before taking action influencing humans' behavior towards perceptions and behavior in maintaining and preserving their environment. This study employs a quantitative approach by conducting a content analysis aiming to understand every word (text) related to land, water, and air through the interpretation of the Quran. This research will produce several criteria as the basic concepts for the development of Islamic values-based green architecture.
\end{abstract}

\section{KEYWORDS:}

Green architecture; religious values; criteria; content analysis

\section{INTRODUCTION}

The existing environmental problems are the result of imbalances, injustices, or exceeded measures. Humans and all their activities have exceeded the limit and surpassed the balance of what has been provided by God. As a consequence, environmental damages such as global warming caused by climate change due to the depletion of the ozone hole, diminished natural resources, and polluted air have been seen clearly on earth. Quran has also mentioned "al-fasad," which means "damage" (Quran ar Ruum verse 41) [1], which is something deviated from the balance, both in small and big scales [2]. Moreover, this condition indicates that humans no longer remember their existence as the representatives on this earth and have stopped understanding and believing that Allah entrusts nature. In other words, humans have an anthropocentric point of view, which changes their beliefs, behaviors, and attitudes that shift the purpose and role of humans toward the environment [2] and see themselves as the center of the universe. In the end, "natureenvironment" is seen as a source of satisfaction for humans that can easily be exploited [3][4].

Although the impacts of environmental problems are increasingly noticeable, these affect the development of a person's lifestyle, trigger innovation in green -labeled industrial products, or building materials that will support the sustainable development movement, as one of the answers to environmental problems. Likewise, the concept of "green building" is one of the solutions to overcome the environmental crisis in the entire development process of the built environment up to now. The development rapidity of green buildings is marked by the awareness of various countries to issue various policies and green ratings set based on the conditions of each country.

The United States Green Build Council (USGBC) is a leading program in the world of green buildings, which created LEED (Leadership in Energy and Environmental Design). It is a system for designing, building, and certifying green buildings [5][6]. Similarly, Australia sought to develop a sustainable development-based property in 2002, namely "Development that meets current needs without sacrificing the ability of future generations to meet their own needs" [7]). Indonesia has also issued the concept of green buildings in the form of "green rating" through the $\mathrm{GBCl}$ (Green Building Council Indonesia).

The statement illustrates that various efforts have been made in dealing with environmental problems such as strategies and/or government's policies, which are referred to as mechanical solutions, while Green Rating is considered as a technical solution [7]. The technical and mechanical aspects are not the only effective solutions in solving environmental problems since some views stated that environmental damage occurs due to a crisis of value [8]. 
Indonesia is located in the Asian Continent, which has a Muslim population of 225.25 million, out of a total population of 258.32 million; this means that as many as $87.2 \%$ of Indonesia's population is predominantly Muslim. Therefore, the value system prevailed in Indonesia does comprise not only the cultural values but also religious values. The community mostly adopts religious values as the highest guideline in behaving. Culture and norms about the prevailing values in society, especially in Indonesia as a country with the largest Muslim community, are strongly influenced by Islamic values. Religion also has a set of rules of how humans manage the relationship with God, fellow humans, and their environment [9]. Hence, it can be said that religion has the highest and absolute truth as the guide for human life and is a core part of the value system that applies to society. The values derived from religion have an essential position and cannot be separated from human life [10]. It is caused by the position of religion as a source of ethics and morals that will regulate the balance of human life and a guide to the truth to make decisions in behaving and taking action. Of course, it affects human perception and behavior, particularly in maintaining and preserving the environment [11].

In this case, the value can be chosen as a strategic approach to achieve specific goals. Therefore, this study is crucial to do to explore religious values taken from the Quran. This study is expecting this value to be a system of belief that can be used as a basis for behavior, ethics, and a positive attitude in managing the environment and the universe. It also can be used as a form of practicing religious values, which in the end, will be able to realize the concept of green buildings successfully. The application of these values is also expected to encourage people to maintain the quality of the environment, reaffirming humans' role as caliphs and at the same time, forming individual subjective norms for their environment.

\section{METHODS}

In this study, there are several steps taken to obtain the expected research results, and the initial stage attempts to find and classify qauliyah verses originating from the Quran. The type of data is textual data obtained through searching keywords: land, water, and air. These three keywords were selected since they were considered as environmental elements that are very vital for human life and other living things as written in QS. al-Furqan (25): 48-49 in which Allah SWT said: "And it is He who sent the winds as good tidings before His Mercy, and We send down from the sky pure water. That we may bring to life, thereby a dead land and give it as a drink to those, We created numerous livestock and men."

The next stage is performing content analysis, which is an attempt to understand each word (text) associated with the Quran. It is a study that focuses on the analysis or interpretation of written material taken from the Quran based on the context. The content analysis approach was chosen because of its compatibility with the theoretical and substantive interests of the issues raised, which are related to the green buildings concept. Content analysis in this research is a quantitative research method, which is a process of interpreting the contextual meaning of a term or content. In this case, it is trying to interpret the definition contained in the Quran related to green buildings concept. Through content analysis, researchers use existing theories to develop initial coding schemes before beginning to analyze the data [9].

The next steps are identifying the value, recognizing the relationship between greenship criteria, and their correlation with the Quranic verse. It is the stage to obtain values that are in line with the principles of green building (Greenship). The Greenship categories are as follows [12]:

1. Appropriate Site Development (ASD)

2. Energy Efficiency \& Conservation (EEC)

3. Water Conservation (WAC)

4. Material Resources \& Cycle (MRC)

5. Indoor Air Health \& Comfort (IHC)

6. Building \& Environment Management (BEM)

This study uses the Greenship criteria, which is a benchmark of green buildings used in Indonesia. The assessment tool called the Greenship was prepared and compiled by the Green Building Council of Indonesia by considering the conditions, nature, regulations, and standards that apply in Indonesia. Greenship was developed by involving building sector actors who are experts in their fields such as architects, building industries, electrical, mechanical technicians, interior designers, landscape architects, and others.

\section{DISCUSSION}

Humans live in a place provided by Allah SWT, both nature and the environment. Therefore, Islam has regulated the good and right way of living for humans, including the ethical way of treating nature and the environment. Allah gave His guidance through the Quran as reading material (Kitab maqrû') and as a book of observation and research (Kitab Manzur), which expresses the real things contained in the Quran [13].

Allah requires us to understand what He said and provide signs for humans to understand the ethics of treating the environment. The ethics go hand in hand with religion and are built entirely on it. Since the environment is genuinely vital for humans as a place to live, it can be ascertained that humans indirectly have a responsibility to ensure environment safety. Al Baqarah (2): 36," and you will have upon the earth a place of settlement and provision for a time." That the relationship between humans and their environment is clearly illustrated, where the environment will significantly influence every living thing; on the contrary, living things themselves will also affect their environment."

The entrenching of guidance and the basics of humans' responsibility in treating nature and environment, certainly must refer back to the teachings and 
instructions of religion, through Divine verses [14]. Nature and environment are verses that mean "signs," "symbols," or evidence from the divine because the Quran is the proof of the existence of Allah and His creations [15]. Besides, the Quran is hudan li al-nas (guidance for humans), as the Quran states: "And on the earth are the signs for certain [in faith]?", (AdhDhariri (51): 20, 21), An-Nahl (16): 89 " And We have sent down to you the Book as clarification for all things and as guidance and mercy and good tidings for the Muslims.", Al-An'am (6): 38: "We have not neglected in the Register a thing. Then unto their Lord they will be gathered".

Humans' obligation to treat the environment well is based on several things, namely that nature (earth), is a place of human habitation, as a gift given by God to humans (QS. Luqman (31): 20). Second, it relates to humans' duty on earth as the guardian of nature preservation, which is God's mandate to humans in terms of istikhlâf (the task of the Caliphate) 12 [12], as stated in QS. Al-An'am [6]: 165, and QS. al-Ahzab (33): 72, "Indeed, we offered the Trust to the heavens and the earth and the mountains, and they declined to bear it and feared it; but man [undertook to] bear it. Indeed, he was unjust and ignorant. " Whereas, the last is that nature-environment is included as the main thing discussed in the Qur'an [16]; "Allah commands humans to take maximum advantage of nature so that happiness and prosperity can be realized." This explication strengthens the existence of humans as the bearers of the mandate of Allah SWT, hoping that humans can realize it in their daily lives.

Thus, humans are required to have certain ethics in treating the environment. They need to have morality and ethical behavior towards the environment, the moral wisdom of humans in associating with their environment and realizing their responsibility to maintain and preserve the environment, which is often known as ri'ayat al-bi'at [17] [18]. It is equivalent to uphold religion, soul, lineage, reason and property as the preservation basis for the primary purpose of religion (al-dharûriyyât al-khams) [19]. As written in QS al-A'raf (7): 85 , "So fulfill the measure and weight and do not deprive people of their due and cause not corruption upon the earth after its reformation. That is better for you if you should be believers." Hence, maintaining the environment is the fundamental basis of one's faith [19], and so the guarantee of humans' continued existence on earth can be achieved.

\section{LAND}

There are three words mentioned by Allah concerning the land in the Quran. Beside the word "alArdhun," there is also the word "al-tin" and the word "al-turab," which means land. Not all verses of the Qur'an mention the term associated with land and the environment, but some of them explain the creation of humans from the soil. This study describes things related to the environment and land. The results of the collection of data, letters, and verses of the Quran, containing the word "land," show six letters and eight verses (see figure 1). Two verses are each found in Surah Taha and al-A'raf, while other surahs contain only 1 verse. The keyword "land" strengthens the existence of land as the best place for fruits, plants, and water-saving that came down from the sky (rain), given by Allah to produce something beneficial for humans and animals. Hence, the land must be protected and preserved in several ways, such as fertilizing the land and greening it by planting trees and/or creating agricultural land. As written in Saheeh Muslim, "The world is beautiful and verdant, and verily God, exalted, has made you His stewards in it, and he sees how you acquit yourselves " [2]. Also, it is contained in QS. AlAraf (7): 58; " And the good land - its vegetation emerges by permission of its Lord; but that which is bad - nothing appears except sparsely, with difficulty. Thus do We diversify the signs for a grateful people ". In the hadith of Bukhari: Prophet Muhammad SAW was encouraged to cultivate trees that are considered a good act. As narrated by Anas bin Malik (RA) that Allah's Messenger (PBUH) said: "There is none among the Muslims who plants a tree or sows seeds. Moreover, then a bird or an animal eats from it but is regarded as a charitable gift for him (Bukhari)".

The description above is in line with the Greenship category, "Appropriate Site Development," which aims to nurture, expand and produce green areas to improve climate quality, and has a significant influence on humans' health and comfort in the open and closed space. In addition, Quran has also emphasized the two benefits of expanding green area namely the existence of benefits that can be felt by humans (Surah Abasa (80): 24-32) and beauty (QS. Al-Naml (27): 60) that can surely be enjoyed by humans in the form of beautiful scenic gardens.

Several verses of the Quran related to land within the scope of this study, conclude that some contents are in line with greenship categories, such as the importance of the site (land) in human life as a place to live, making humans wise, and caring for it without causing any damage. Another value we can take from the Quran is the fact that land is a place for planting, sowing seeds, and planting trees to produce fertile, beautiful, and of course, green areas. Islam has emphasized the importance of conservation and revitalization in a dead land.

\section{WATER}

Water is the source of life and plays a vital role in this universe. And We have sent down rain from the sky in a measured amount and settled it in the earth. And indeed, We are able to take it away (Surah alMu'minun (23): 18-19), "... and made from water every living thing..." (Surat al-Anbiyaa '(21): 30) In this verse, Allah mentions His infinite blessings to His servants by bringing down the rainwater as what needed by the living things. It is not too much that it can damage the earth and buildings, and not so little that it is insufficient for agriculture and cropping [20]. In QS. al-An'am (6): 99 "And it is He who sends down rain from the sky, and We produce thereby the growth of all things. We 
produce from it greenery from which We produce grains arranged in layers. And from the palm trees - of its emerging fruit are clusters hanging low. And [We produce] gardens of grapevines and olives and pomegranates, similar yet varied. Look at [each of] its fruit when it yields and [at] it is ripening. Indeed in that are signs for a people who believe."(Surah al-Baqarah (2): 22). Then, "[He] who made for you the earth a bed [spread out] and the sky a ceiling and sent down from the sky, rain and brought forth thereby fruits as provision for you. So do not attribute to Allah equals while you know [that there is nothing similar to Him].", then in QS. Abraham (14): 32 "It is Allah Who created the heavens and the earth and sent down rain from the sky and produced thereby some fruits as provision for you and subjected for you the ships to sail through the sea by His command and subjected for you the rivers.

Moreover, consecutively, similar versions are found in QS. An-Nahl (16): 10-11 and QS. An-Nahl (16): 65, al-Kahfi (18): 45, at-Thaahaa (20): 53, al-Hajj (22): 63, and QS. al-Anfal (8): 11 "([Remember] when He overwhelmed you with drowsiness [giving] security from Him and sent down upon you from the sky, rain by which to purify you and remove from you the evil [suggestions] of Satan and to make steadfast your hearts and plant firmly thereby your feet). This verse explains that the function of rain is to purify or cleanse.

The explanation above asserts that human life depends on water, and water has become an essential factor in shaping the lives of humans and other living things. Without water, life is meaningless. It has been explained in the Quran: "Have those who disbelieved not considered that the heavens and the earth were a joined entity, and We separated them and made from water every living thing? Then will they not believe?" (Surah al-Anbiya '(21): 30).

A total of 31 surahs and 38 verses (see figure 1) illustrate that water has an essential meaning for the emergence of life on earth, and that water coming down from the sky will bring earth and all its contents to life, as well as will turn the soil fertile. Also, with water, a variety of flavorous and colorful plants and fruits will grow and make the earth greener. In addition, with the power of God, water is sent down with the help of the wind since it is created to move the clouds where He wants.

The results of content analysis illustrate the order of doing water conservation and emphasis the importance of frugality in using water. Of course, this is in line with the greenship category of "water conservation (WAC)." It is an effort to promote the frugality in using water, which will automatically reduce clean water consumption and wastewater. Of course, this will further clarify that the guidelines for behavior towards the environment have all been written and explained in the Quran containing values that are in line with the sustainable concept.

\section{AIR}

The Quran describes the wind as one of the signs of God's power (Surah al-Rûm (30): 40). God subdues the wind for the benefit of humankind as a blessing (QS. Shad (38): 36, and Saba (34): 12), including as a part of the process of water and rain (Surah al-Baqarah (2): 164, al-Rûm (30): 48, and Fathir (35): 9), the process of pollinating plants (QS. Al-Hijr (15): 22), and sailing the ship in the sea (QS. Yunus (10): 22 and al -Syura (42): 33). Then in QS. Al-Furqaan (25): 48 " And it is He who sends the winds as good tidings before His mercy, and We send down from the sky pure water." This rainwater is considered as a mercy and has the characteristic called "Ma'aan thohuran that means pure water."

Allah reveals the commands in the Quran with very good parables stating that wind is blown to bring clouds, and then rain falls from the gap. Also, wind enables humans to walk on land and sail on the sea, and the wind is blown for plant marriage. Wind does not only have significant roles for the life cycle on this earth but also has a massive role in giving a space comfort that affects the health of humans who live in it. In this case, wind can be used for ventilation to enable the exchange of air inside the room for removing heat, and the availability of pure air to breathe will be sufficient. Moreover, in the end, it indirectly will maintain humidity and temperature that is comfortable for residents in the building. Adequate ventilation will increase the productivity of the inhabitants' activities and prevent diseases such as respiratory infections. By utilizing wind movement to make natural ventilation, the mechanical device's utilization will decrease, and it will reduce excessive energy consumption.

\section{CONTENT ANALYSIS}

The distribution of the content analysis results from each factor like land, water and air can be seen in Figure 2, and the overall keywords can be seen in Figure 3. Overall, there are 172 keywords as the results of the previous keywords grouping. In detail, Rainwater has the highest score (36), followed by benefits of rain (25), Land (14), Wind (13), Fruits (12), Vegetation, and Clean Water (9), Plants (8) and Parks (7). The results of these keywords are put into the Greenship criteria which shows that Water Conservation category (WAC) gets the highest position that is 74 points, followed by the Appropriate Site Development (ASD) category (66 points), and 13 points for Energy Efficiency and Conservation (EEC) (see Table 1). 


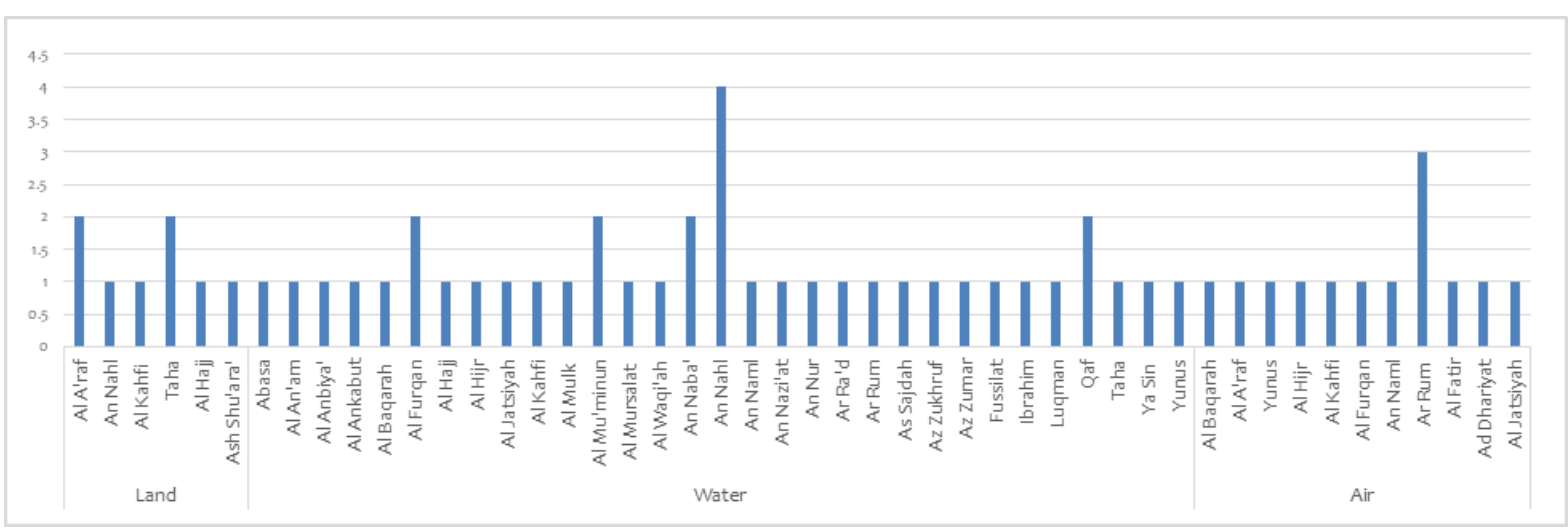

Figure 1. Surah and verses distribution based on Land, Water and Air keywords

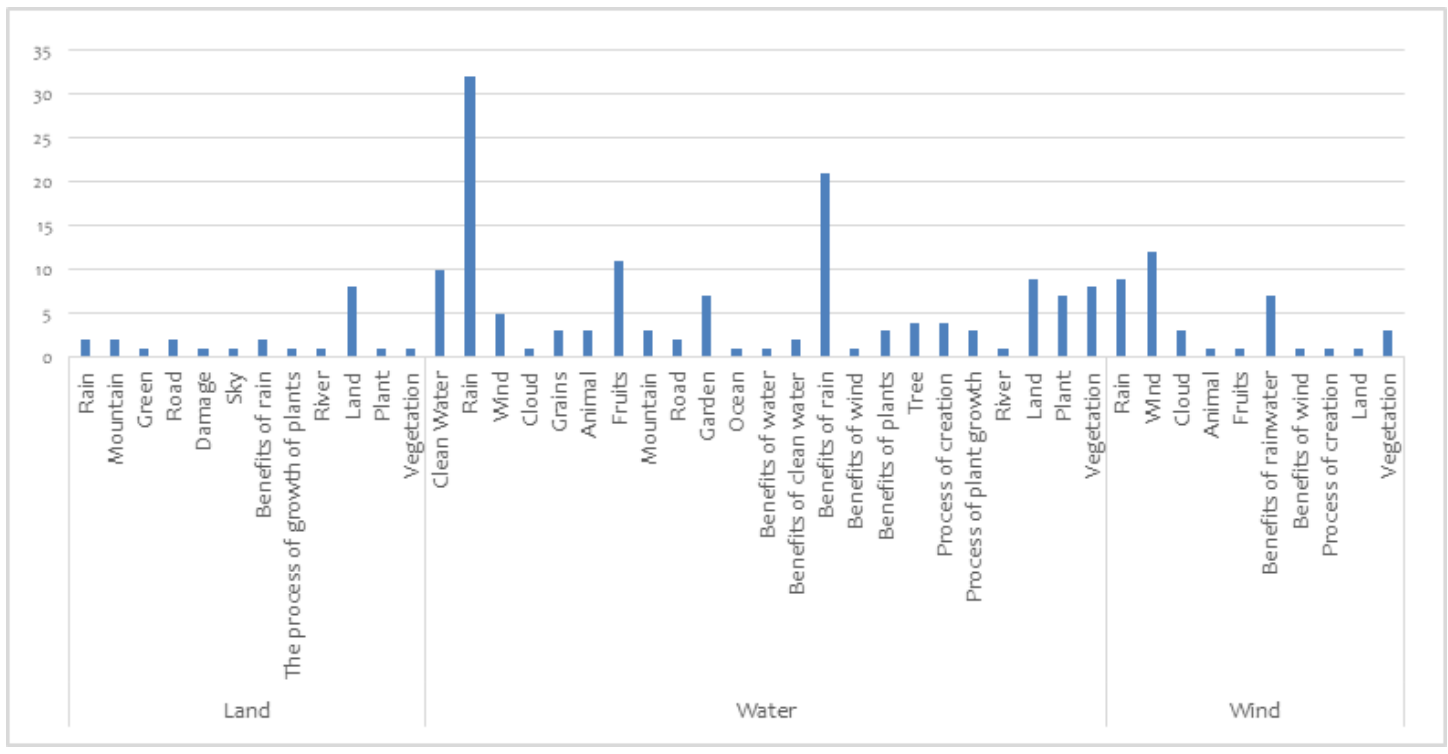

Figure 2. Keywords Distribution from content analysis based on Land, Water and Air keywords

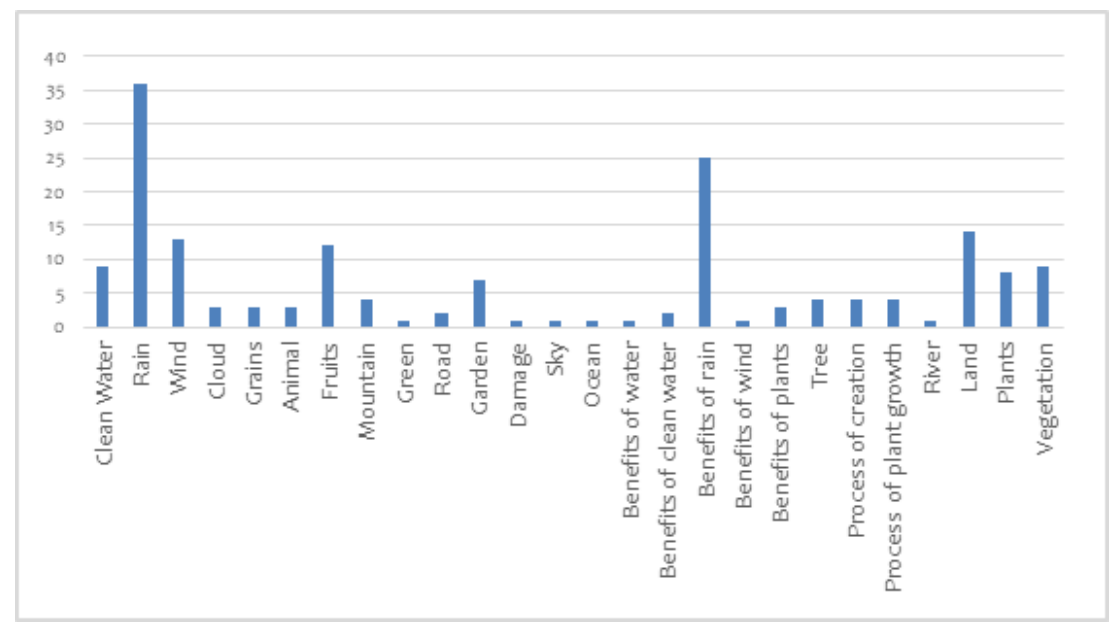

Figure 3. All keywords from the content analysis [source in IEEE format] 


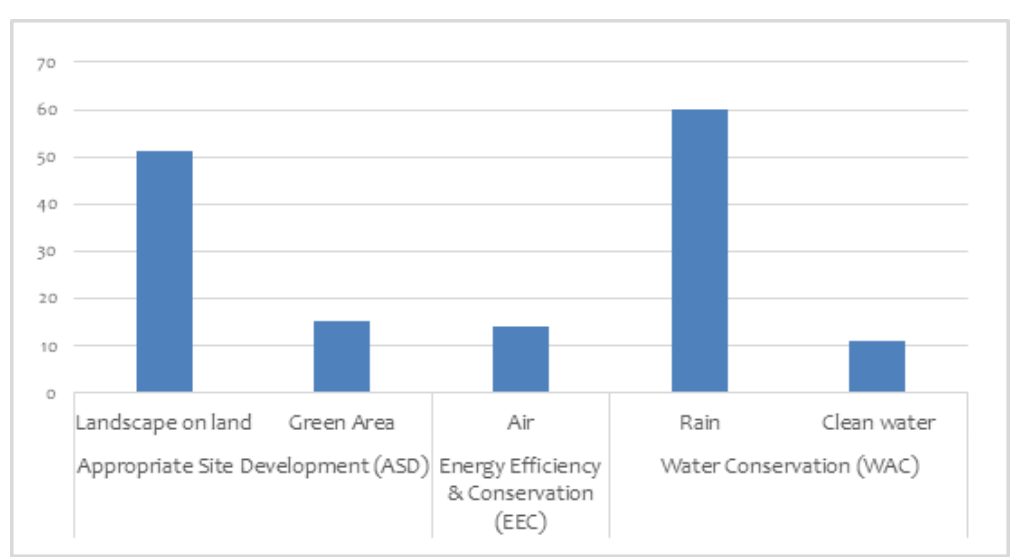

Figure 4. Geenship Criteria based on Islamic Values [source in IEEE format]

Tabel 1. Process method and Results

\section{1}

Search for the Qur'an

keywords: Land, Water and Air

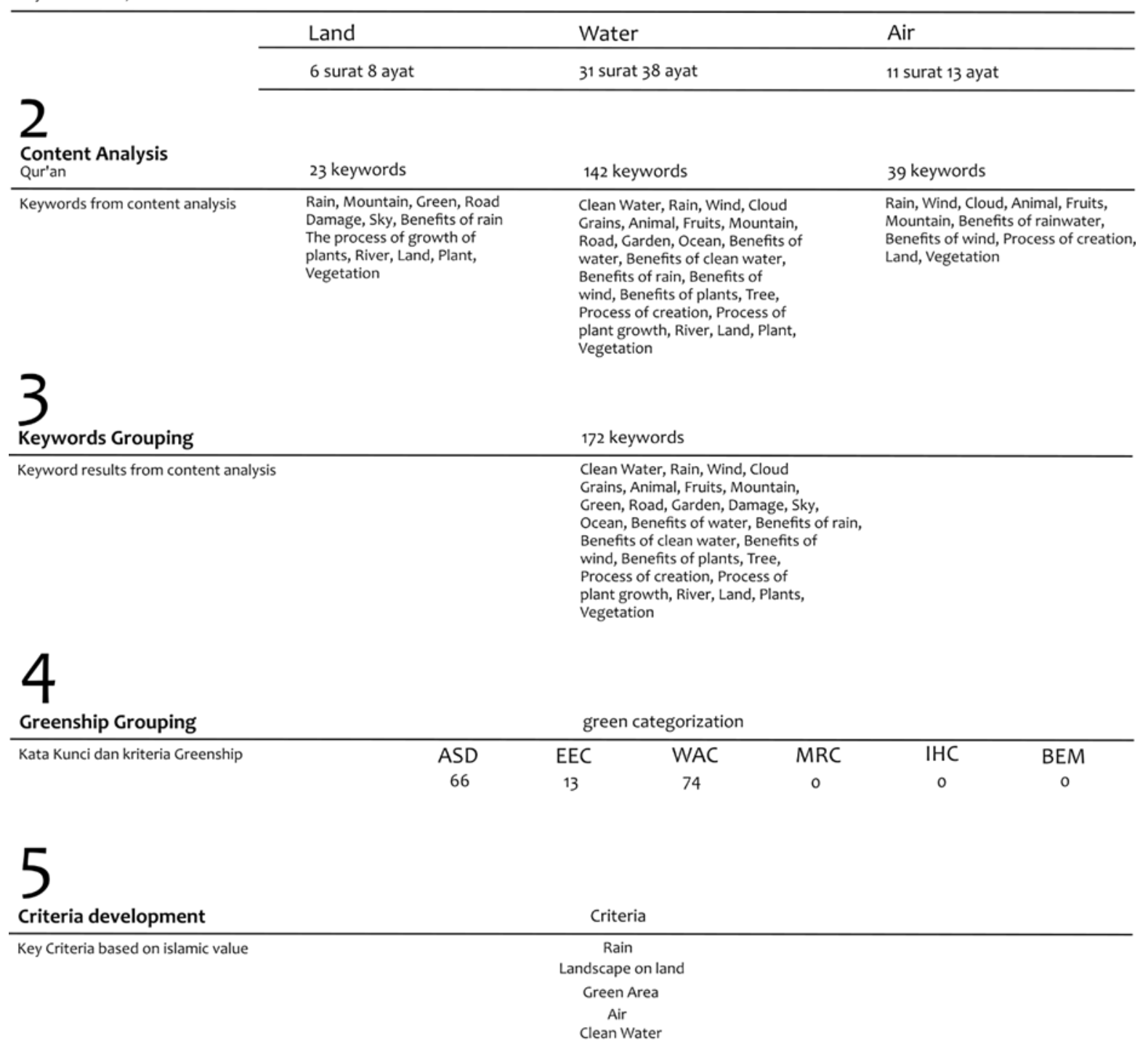


The results of this study elucidate that Islam has strictly and detailedly emphasized the importance of balance and harmony in managing and using the existing natural source. Water, land and air are three crucial elements for living creatures' life. Since they have limitation, life may be endangered if those three factors are not wisely utilized for the present and future time.

Table 1 shows the greenship criteria based on Islamic values. It emphasizes three main criteria; Appropriate Site Development (ASD), Energy Efficiency \& Conservation (EEC), and Water Conservation (WAC). The highest points are on WAC criteria (74), followed by ASD (66), and EEC 13 points. With these results, we can gain knowledge (al-'tibar) from what has been conveyed in the Qur'an such as the following ones:

1. Using clean water by utilizing rainwater to be used wisely throughout the entire process of developing green architecture. An explanation of rainwater in the Quran is always described as a source of water came down from the sky as Allah gives it. The result of the content analysis shows 60 points for rainwater and only 11 points for clean water (figure 4). It means utilizing rainwater is one of the efforts that humans can do very well to be able to meet humans' needs on earth.

2. To develop green areas and landscape management as parts of green architecture development. ASD development made based on Islamic values concern with the efforts to maximize land management such as farming, agriculture, spreading seeds and planting trees. Landscape management is the main emphasis in Islamic values that brings 51 points compared to the green area that has 15 points (see figure 4). If this process can be carried out, it will revive dead land and give a good impact on realizing the lives of humans and other creatures on earth, as well as support the realization of green architecture.

3. Take advantage of and make the best use of (alIntifa') wind movements for the benefit of mankind as one of the alternative energies that is a part of energy conservation.

These religious values are very suitable if applied in Indonesia as a vast country that has a lot of potentials to be developed. Abundant natural resources supported by Indonesia's vast territory is also one possibility that must be utilized optimally.

The geographical position of Indonesia from Sabang to Merauke, with two seasons, namely the dry season and the rainy season, provides many different benefits. High rainfall will be able to meet the water needs of the earth, and plants can flourish, multiply rapidly. Therefore, land development, landscape management to develop green areas, and landscape management are crucial to be applied to preserve nature and at the same time, meet the needs of living things on earth. And of course, if these values are used in Indonesia will support the successful application of the concept of green architecture.

\section{CONCLUSION}

A human can improve their attitude and behavior towards the earth by learning and taking the positive values contained in the Qur'an. They can also increase their awareness of maintaining and preserve nature as in accordance with the instructions given by God (AlIslah). These values are the starting point of ethics for the environment and as part of realizing the green architecture concept comprehensively.

Quran has signs and signals to be interpreted and used as a guide which primarily contains the principles of life and has an essential role in environmental conservation and protection. Moreover, Islamic values taken from the Quran provide a moral framework which can also be used as a framework for developing green architecture.

Finally, the results of this research in the future can be further developed by following the criteria of green buildings based on Islamic values for the benefit of developing Islamic architectural design concepts.

\section{REFERENCES}

[1] M. Sani, “Learn Quran,” 2018. [Online]. Available: https://tafsir.learn-quran.co/id/topics.

[2] A. Bagader, A. El-Sabbagh, M. Al-Glayand, and M. Samarrai, "Environmental Protection in Islam (part 1 of 7): A General Introduction," Islam Religion, 2006. [Online]. Available: http:// www.islamreligion.com/articles/307.

[3] R. Z. Harahap, "Etika Islam dalam Mengelola Lingkungan Hidup," Edu Tech, vol. 1, no. 1, 2015.

[4] A. Aziz, "KONSERVASI ALAM DALAM PERSPEKTIF ETIKA ISLAM; TANTANGAN DAN TUNTUTAN GLOBALISASI," Akademika, vol. 19, no. 2, pp. 304-321, 2014.

[5] U. G. B. Council, LEED: Leadership in energy and environmental design. Washington: Weltec Engineering and Consultant Ltd., 2011.

[6] O. Johansson, "The spatial diffusion of green building technologies: The case of Leadership in Energy and Environmental Design (LEED) in the United States," International Journal of Technology Management \& Sustainable Development, vol. 10, no. 3, pp. 251-266, 2012.

[7] I. Borowy, Defining Sustainable Development for Our Common Future A History of the World Commission on Environment and Development (Brundtland Commission). London: Routledge, 2013.

[8] M. Romli, "Mewujudkan Pembangunan Berkelanjutan melalui Prinsip-Prinsip Etika dan Moral Islam Ringkasan." Institut Pertanian Bogor, Bogor, 2016.

[9] W. Jenkins and C. K. Chapple, "Religion and Environment," Annual Review of Environment and Resources, vol. 36, pp. 441-463, 2011.

[10] M. N. Mamat, S. F. Mahamood, and I. Ismail, 
"Islamic Philosophy on Behaviour - Based Environmental Attitude," Procedia - Social and Behavioral Sciences, vol. 49, pp. 85-92, 2012.

[11] M. H. Efendi, M. H. Irawati, F. Rochman, and A. Gofur, "Environmental Conservation Education by Applying Islamic Values," Journal of Education \& Social Policy, vol. 4, no. 2, pp. 180186, 2017.

[12] Green Building Council Indonesia, Greenship Rating Tools. Jakarta: GREEN BUILDING COUNCIL INDONESIA, 2013.

[13] Safrilsyah dan Fitriani, "Agama Dan Kesadaran Menjaga Lingkungan Hidup," Subtantia, vol. 16, no. April, pp. 61-78, 2014.

[14] M. M. Dj, "Kerusakan Lingkungan Perspektif Al-Qur'an (Studi Tentang Pemanasan Global)," Universitas Islam Negeri Syarif Hidayatullah Jakarta, 2010.
[15] I. Sarkar, "Islamic Values And Environmenta Disquiet," Philosophy and Progress, vol. LVIILVIII, 2015.

[16] F. Khalid, "The Environment in Islam," The Environment In Islam, no. September, p. 17, 2010.

[17] M. Nafisah, "Al-Quran dan Konservasi Lingkungan (Suatu Pendekatan Maqâsid al- Syarî 'ah)," UIN Syarif Hidayatullah Jakarta, 2017.

[18] T. Maisaroh, "Akhlak Terhadap Lingkungan hidup Dalam Al-Quran (Studi Tafsir AlMishbah)," UIN Raden Intan Lampung, 2017.

[19] O. M. Ashtankar, "Islamic perspectives on environmental protection," International Journal of Applied Research, vol. 2, no. 1, pp. 438441, 2016.

[20] Ustadz Abu Abdillah Syahrul Fatwa bin Lukman, "Melestarikan Lingkungan Hidup," 1435 H_2014 M, no. 143 . 